\title{
Experimental evidences on the potential of prebiotic fructans to reduce the risk of colon cancer
}

\author{
B. Pool-Zobel ${ }^{1}$, J. van $\operatorname{Loo}^{2}$, I. Rowland ${ }^{3}$ and M. B. Roberfroid ${ }^{4}$ \\ ${ }^{1}$ Institute for Nutrition, Department of Nutritional Toxicology, Friedrich Schiller University Jena, Dornburger Street 25, \\ 07743 Jena, Germany \\ ${ }^{2}$ ORAFTI, Aandorenstraat 1, 3300 Tienen, Belgium \\ ${ }^{3}$ University of Ulster, Coleraine, Co Londonderry, BT52 ISA, UK \\ ${ }^{4}$ Rue du Rondia 7A, 1348 Louvain-la-Neuve, Belgium
}

\begin{abstract}
Inulin is extracted from the chicory root. It is a set of fructans with its monomers $(n=2-65)$ linked by means of $\beta(2-1)$ bonds. This linkage cannot be hydrolysed by either pancreatic or by brush border digestive enzymes in the upper intestinal tract of humans. As such the carbohydrates arrive in the colon, where they are fermented by bifidobacteria and other lactic acid producing bacteria, thus enhancing their relative populations in the gut. Recent research in experimental animal models revealed that inulin has significant anticarcinogenic properties. It acts chemopreventively by reducing the incidence of azoxymethane (AOM) - induced aberrant crypt foci and tumours in the colon. These effects may be due to the stimulation of bifidobacteria, which themselves have been shown to act as antigenotoxic in the colon and to reduce AOM-induced tumours. Also fermentation products, including the short-chain fatty acid butyrate, could contribute to the protective effects. In this case a mechanism may be the induction of apoptosis of already transformed cells. The experimental evidence from animal studies and from studies elucidating potential mechanisms strongly supports the possibility that inulin will contribute to reducing risks for colon cancer in humans. In order to obtain more insight into this possibility, human dietary intervention studies relating biomarkers of reduced risk to inulin consumption are needed.
\end{abstract}

Inulin: Oligofructose: Aberrant crypts: Chemoprevention: Anticarcinogenic food ingredients

\section{Introduction}

Cancer is a popular generic term for malignant neoplasm, a great group of diseases with unknown and probably multiple causes, arising in tissues composed of potentially dividing cells. The basic characteristic of cancer is the transmissible abnormality of cells that is manifested by reduced control over cellular functions, which cause serious adverse effects to the host through invasive growth and metastases. Several factors of environmental and genetic origin affect cancer incidence. The most important environmental contributors are estimated to be the diet, causing approximately $35 \%$ of all cancer deaths (Doll, 1991), and lifestyle factors (tobacco, reproductive behaviour, and alcohol). Additionally, approximately some $20 \%$ of all cancer deaths are due to infections, occupation, pollution, industrial products, medicines, geophysical and hereditary factors (Doll \& Peto, 1981; Fearon, 1997). Overall it appears that approximately 75$80 \%$ of cancers can be influenced by either lifestyle or diet, and it would be desirable to change dietary habits in a forward-looking way of cancer prevention. One of the approaches could be to advise the more frequent consumption of specific food groups or dietary ingredients to shift the balance of food intake to favour a protective diet (Doll, 1996).

Inulin and oligofructose could be such effective food ingredients to be included in this type of strategy. They are natural constituents of many common plant foods such as onion, garlic, tomato, banana, wheat, etc. and, as reviewed below, they have anticarcinogenic potential. Their average consumption in the normal human diet has

\footnotetext{
Abbreviations: ACF, aberrant crypt foci; AOM, azoxymethane; DMH, dimethylhydrazine; GSH, glutathione; GST, glutathione S-transferase; LAB, lactic acid producing bacteria.

Note: For the definition of the terms inulin and oligofructose please refer to the introductory paper (p. S139) and its footnote.

* Corresponding author: Prof. Dr. rer. nat. Beatrice L. Pool-Zobel, tel +49 3641 949670, fax +49 3641 949672, email b8pobe@uni-jena.de
} 
been evaluated to amount to several grams per day (Moshfegh et al. 1999; Van Loo, 1995). Inulin is industrially obtained from chicory roots by hot water extraction, followed by refining and spray drying. It is thought that chicory inulin and its low and high molecular weight fractions owe their nutritional properties to the presence of the $\beta(2-$ 1) bond, which cannot be hydrolysed by the pancreatic nor by the brush border hydrolytic enzymes of humans (Schneemann, 1999). As such inulin and oligofructose escape digestion in the upper intestinal tract and arrive almost quantitatively $(>90 \%)$ in the colon (Ellgard et al. 1997). There these non-digestible oligosaccharides are completely fermented. Hereby they selectively promote the growth of certain groups of bacteria. Amongst these are the bifidobacteria and the lactobacilli, both of which produce lactic acid and are considered to be indicators of a well-balanced intestinal flora (Gibson \& Wang, 1994). This modified intestinal flora and the metabolites, which it produces, interact with the surface of the intestinal tract in the human body and cause physiological beneficial effects.

Inulin and oligofructose have been subjected to extensive in vitro and in vivo (experimental models) research (Van Loo et al. 1999). At present, the relevance of most observed properties has been confirmed in human dietary intervention studies. The prebiotic effect (Gibson \& Roberfroid, 1995; Roberfroid et al. 1998; Kruse et al. 1999), as well as modulation of lipid metabolism (Williams, 1999), increased calcium absorption (Coudray et al. 1997; Van den Heufel et al. 1999), modulation of the immune system in young children (Saavedra et al. 1999) and modulation of gut function (Den Hond et al. 2000) are important physiological properties that may have significant health promoting impact in humans.

Recently an impressive variety of studies in experimental anticancer models has been performed. This review intends to bring together and discuss these data, reflect on state of art, as well as on research necessary to understand putative properties of risk reduction for cancer by these specific types of prebiotics.

\section{Prevention of cancer and related endpoints in animal experiments}

\section{Prevention of chemically induced aberrant crypt foci and colon cancer}

Several experiments with inulin and oligofructose have been performed using one of the most commonly employed animal models to determine preneoplastic lesions in the colon of rats (Bird, 1987). The carcinogenic compound used is azoxymethane (AOM), an alkylating derivative of dimethylhydrazine $(\mathrm{DMH})$, that specifically targets the colon of rats, where it induces DNA damage (Pool-Zobel et al. 1996) and tumours. The highest tumour incidence is in the distal part of the colon. Rats $(n \geq 10)$ are injected (e.g. subcutaneously) with two AOM doses $2 \times 15 \mathrm{mg}$ AOM/kg body weight at an interval of 1 week. The tumours appear after a period of 45-52 weeks. Intermediate endpoints induced by AOM can be detected already after 8 weeks, since it produces large quantities of preneo- plastic lesions in the colon, called aberrant crypt foci (ACF). These abnormalities are due to a thickening of the wall in the pericarp of the colon crypts that can be stained and counted. Numerous aberrant crypts occur together and are visible as aberrant crypt foci (ACF). Most of these lesions, however, are eliminated by repair mechanisms. Only some of them develop into tumours, of which mainly those with high numbers of aberrant crypts per foci (multiplicity) are associated with cancer risk (Magnuson et al. 1993). The application of the model using AOM as the initiator has been developed to study chemoprevention of colon tumours (Wargovich et al. 1992; Pereira et al. 1994). An overview of the variations of this model that has been used to study inulin and oligofructose for preventive properties are presented in Table 1.

At least three studies show a reduction of crypt numbers and multiplicity, when adding inulin (10\%) to the diet; Rowland et al. 1998; Coles et al. 2000). In one case (Reddy et al. 1997), it was observed that the effect of inulin is numerically more important than the effect of the oligofructose (Fig. 1). This was attributed to the lower fermentation rate of the inulin, which as a consequence may arrive in more distal parts of the colon, where the injected carcinogen (AOM) exerts its damaging activity (adapted from Reddy et al. 1997). Other authors could confirm this in a study where the whole range of chicory fructans was compared. Verghese et al. (2002a) observed an increasing protection of oligofructose $<$ inulin $<$ long-chain inulin $<$ a mixture of inulin+oligofructose which is a specific mixture of short- and longchain inulin fractions (Verghese et al. 2002a, Van Loo \& Jonkers, 2001). However, there is also a report where in a similar experimental approach with oligofructose no reduction of ACF was observed (Gallaher \& Khil, 1999).

In another experiment (Rowland et al. 1998), it was observed that the combination of the prebiotic inulin and the probiotic B. longum inhibit AOM-induced aberrant crypt foci in a synergistic manner. Especially the effect on the foci with multiplicity of over four crypts, which are thought to be the most relevant markers for tumour formation, may be considered of importance in this context (Fig. 2). This was the first demonstration of an effect now described as 'synbiotic', which has been confirmed by another group (Gallaher \& Khil, 1999).

A more recent study shows that the effect of inulin is dose related. By increasing the concentrations of inulin to 2.5, 5 and $10 \%$ in the diet (Verghese et al. 2002a), an increasingly more visible impact on reduction of ACF incidence is apparent. These authors, moreover, have also recently shown that the incidence of colonic tumours is reduced after life-long feeding of $10 \%$ inulin to the rat (Verghese et al. 2002b). Moreover, when offering inulin only before or only after the carcinogenic AOM injection, or by continuously administering inulin throughout the whole experiment, the effect of the prebiotic compound given either during the initiation phase (I), or during the promotion phase $(\mathrm{P})$ or during the whole carcinogenic process $(\mathrm{I}+\mathrm{P})$ was investigated. It was observed that the highest impact on limiting the numbers of tumours and/ or reducing the average size of the tumours was obtained 
Table 1. Overview of the different experimental lay-outs using inulin and oligofructose based on the AOM/ACF model

\begin{tabular}{|c|c|c|c|c|c|c|c|}
\hline Test substance & Type of diet & $\begin{array}{l}\text { Feeding } \\
\text { scheme () }\end{array}$ & $\begin{array}{l}\text { Number of } \\
\text { rats }(n)\end{array}$ & $\begin{array}{l}\text { Type of rat } \\
\text { (age) }\end{array}$ & $\begin{array}{l}\mathrm{AOM} \\
(\mathrm{mg} / \mathrm{kg} \\
\mathrm{BW})\end{array}$ & Biomarker & Reference \\
\hline Oligofructose (10\%) & $\begin{array}{l}\text { AIN-76A } \\
\text { semi-puri- } \\
\text { fied }\end{array}$ & $\mathrm{I}+\mathrm{P}$ & 12 & $\begin{array}{l}\text { male F344 } \\
(5 \mathrm{w})\end{array}$ & 15 & ACF/multiplicity & Reddy et al. 1997 \\
\hline \multicolumn{8}{|l|}{ Inulin* (10\%) } \\
\hline $\begin{array}{l}\text { Inulin* }(5 \%) \\
+ \text { B. longum }\left(10^{9}\right)\end{array}$ & $\begin{array}{l}\text { CO25 high } \\
\text { fat diet }\end{array}$ & $\mathrm{P}$ & 15 & $\begin{array}{l}\text { male } \\
\text { Sprague- } \\
\text { Dawley } \\
(3-4 \mathrm{w})\end{array}$ & $12 \cdot 5$ & ACF/multiplicity & $\begin{array}{l}\text { Rowland et al. } 1998 \\
\text { Bolognani et al. } \\
2001\end{array}$ \\
\hline \multirow[t]{3}{*}{ Inulin* $(10 \%)$} & AIN 93G & & 12 (ACF) & $\begin{array}{l}\text { male F344 } \\
(5 \mathrm{w})\end{array}$ & 16 & ACF/multiplicity & $\begin{array}{l}\text { Verghese et al. } \\
2002 b\end{array}$ \\
\hline & & I & 20 (tumors) & & & $\begin{array}{l}\text { Tumours after } \\
45 \text { weeks }\end{array}$ & \\
\hline & & $\begin{array}{l}\mathrm{P} \\
\mathrm{I}+\mathrm{P}\end{array}$ & & & & & \\
\hline $\begin{array}{l}\text { Inulin* } \\
(2 \cdot 5 ; 5 \text { and } 10 \%)\end{array}$ & AIN $93 \mathrm{M}$ & $\mathrm{I}+\mathrm{P}$ & 12 & $\begin{array}{l}\text { male F344 } \\
(52 \mathrm{w})\end{array}$ & 10 & ACF/multiplicity & $\begin{array}{l}\text { Verghese et al. in } \\
\text { press } 2002 a\end{array}$ \\
\hline $\begin{array}{l}\text { Oligofructose }(10 \%) \\
\text { Inulin }(10 \%) \\
\text { Inulin* }+ \text { oligofructose } \\
(10 \%) \\
\text { Maltodextrin as } \\
\text { placebo }\end{array}$ & AIN 93G & $\mathrm{I}+\mathrm{P}$ & 12 & $\begin{array}{l}\text { male F344 } \\
(5 \mathrm{w})\end{array}$ & 15 & ACF/multiplicity & $\begin{array}{l}\text { Verghese (report } \\
\text { prepared for } \\
\text { ORAFTI) }\end{array}$ \\
\hline
\end{tabular}

I: initiation phase, rats are fed with the pre/probiotics prior to and during injection with $\mathrm{AOM}$; $\mathrm{P}$ : progression phase, rats are fed with the pre/probiotics after injection with $\mathrm{AOM} ; \mathrm{I}+\mathrm{P}$ : initiation and progression phases, rats are fed with the pre/probiotics before and after injection with AOM, throughout life; AOM: azoxymethane; ACF: aberrant crypt foci.

* In these studies the inulin used was long-chain inulin idenitified as HP-Inulin.

when inulin was applied during the promotion phase, although the dietary supplementation during initiation phase also reduced the number of tumours. In this model, tumours in the small intestine also develop and these were also dramatically reduced in the inulin feeding groups. In this case the effect of supplementation during the initiation phase was about as important as during the promotion phase (Verghese et al. 2002b).

\section{Modulation of sporadic cancers in transgenic APC ${ }^{M I N}$ mouse model}

Inulin may also modulate the occurrence of colon tumours, which are not chemically induced. Studies were performed with a genetically predetermined model, the $\mathrm{APC}^{M I N}$ mouse. This transgenic mouse contains a nonsense mutation in the murine APC-gene and it is strongly predisposed to developing intestinal tumours at a relatively young age. It comes close to reflecting the situation of patients with familial adenomatous polyposis (FAP), or of individuals carrying the first APC mutation in somatic cells and who are then later predisposed for developing sporadic colon cancer. As is shown in Fig. 3, dietary supplementation with oligofructose (from sucrose) caused a reduction in the incidence of colonic tumours but not of small intestinal tumours (Pierre et al. 1997). The authors moreover, observed that the oligofructose-fed mice had a better-developed gut associated lymphoid tissue (GALT).

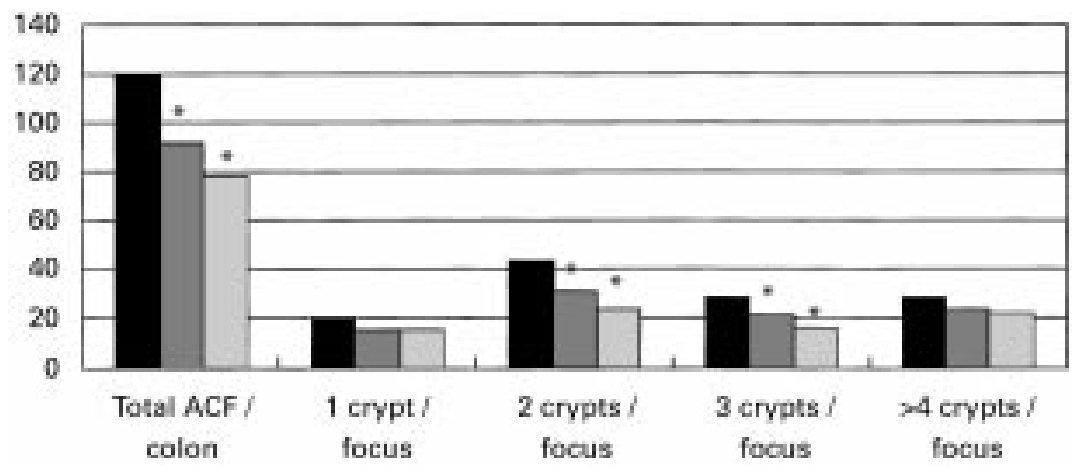

Fig. 1. Life-long feeding of inulin and oligofructose suppresses formation of aberrant crypt foci in the rat colon. Data from Reddy et al. (1997). $=$ Control $4, \quad=10 \%$ oligofructose, $\square=10 \%$ inulin. 

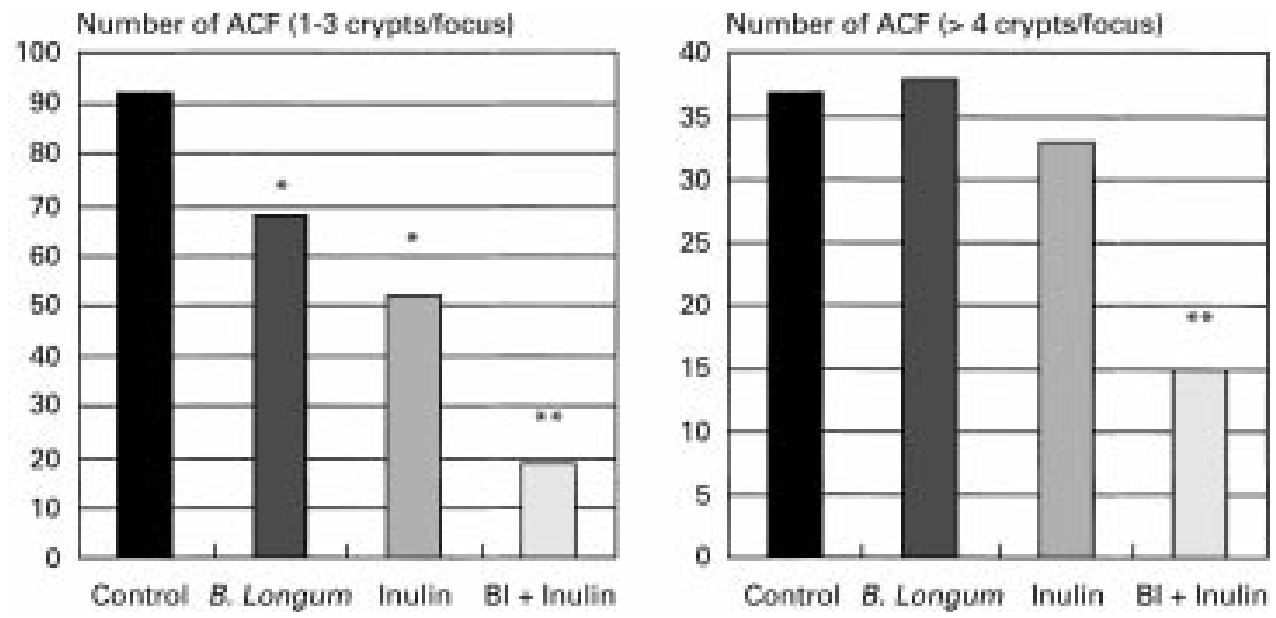

Fig. 2. B. longum and inulin (given during the progression phase) synergistically suppress preneoplastic lesions in the colon of rats. Data from Rowland et al. (1998).

In a similar model, Mutanen et al. (2000) compared the impact of a non-specified fraction of chicory inulin with other prebiotic food ingredients, added at higher dosage levels. Inulin was not effective at these low concentrations significantly different from the non-fibre control.

\section{Mechanisms-directed experimental approaches}

\section{Bifidobacteria, production and potential role as modifiers of cancer risk factors}

Bifidobacteria are present in large amounts subsequent to inulin and oligofructose consumption (Gibson et al. 1995; Kleessen et al. 1997) and these bacteria are expected to contribute to the protective effects of the prebiotics (Gibson \& Wang, 1994). One important mechanism is probably the detoxification of genotoxins in the gut. This has been shown experimentally in animal models using the rat colon carcinogen 1,2-dimethylhydrazine (procarcinogen from which AOM is produced) and determining end points ranging from tumorigenesis (Singh et al. 1997) (Fig. 4), to ACF (Reddy, 1998), down to DNA damage induction (Pool-Zobel et al. 1996) (Fig. 5), all of which were markedly reduced. Owing to the complexity of cancer initiation, of cancer progression and of the exposure situation in the gut, many types of interactions between DMH metabolites and Bifidobacteria may be envisaged to be occurring in the gut. Notably some of our newer studies have shown that short-lived metabolite mixtures isolated from milk fermented with strains of L. bulgaricus and $S$. thermophilus are more effective in deactivating etiological risk factors of colon carcinogenesis than cellular components of the micro-organisms (Wollowski et al. 1999). Depending on the nature of the exposing risk factor, different mechanisms including enhanced decomposition or scavenging can be potential biochemical mechanisms involved.

\section{Inactivation of carcinogens by modification of toxifying and detoxifying enzymes}

Lactic acid producing bacteria (LAB), and fermented milk products containing LAB, or having bifidogenetic properties affect gut flora enzyme activities associated with colon carcinogenesis (Ling et al. 1994). These enzymes, namely azoreductase, nitroreductase, $\beta$-glucuronidase, $\beta$-glucosidase and $7 \alpha$-dehydroxylase are expected to influence the carcinogenic impact of endogenous toxic and genotoxic compounds (Rowland, 1991). Examples
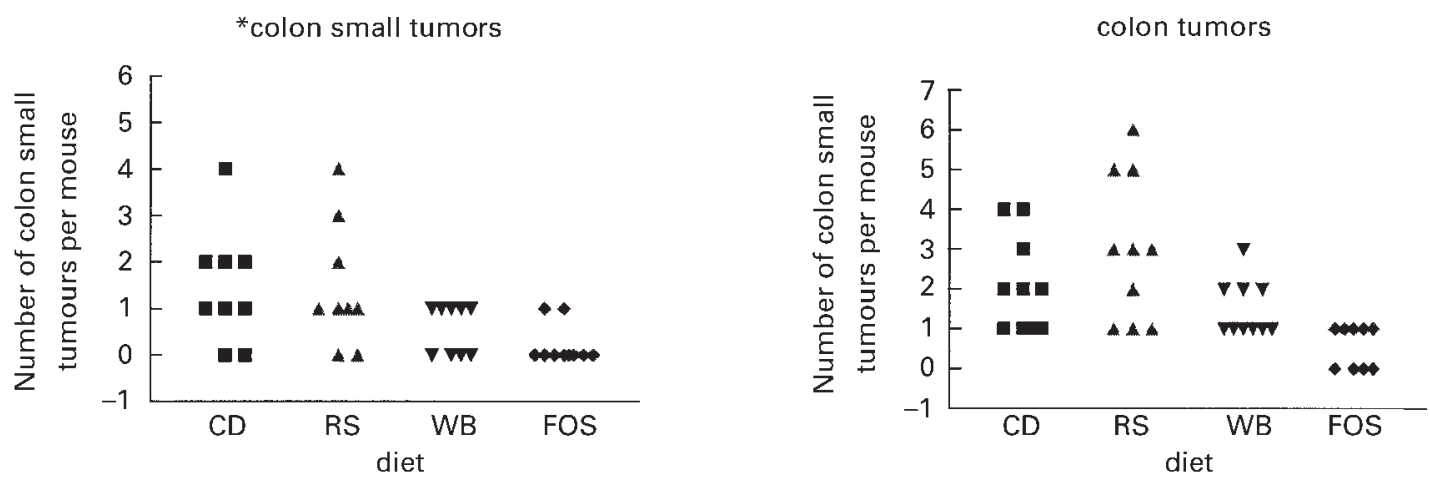

Fig. 3. Oligofructose (from sucrose) reduces the occurrence of colon tumors and develop gut associated lymphoid tissue in APC ${ }^{M I N}$ mice. Data from Pierre et al. (1997). $\mathbf{\square}=\mathrm{CD}, \boldsymbol{\Delta}=\mathrm{RS}, \boldsymbol{\nabla}=\mathrm{WB}, \diamond=$ FOS. 


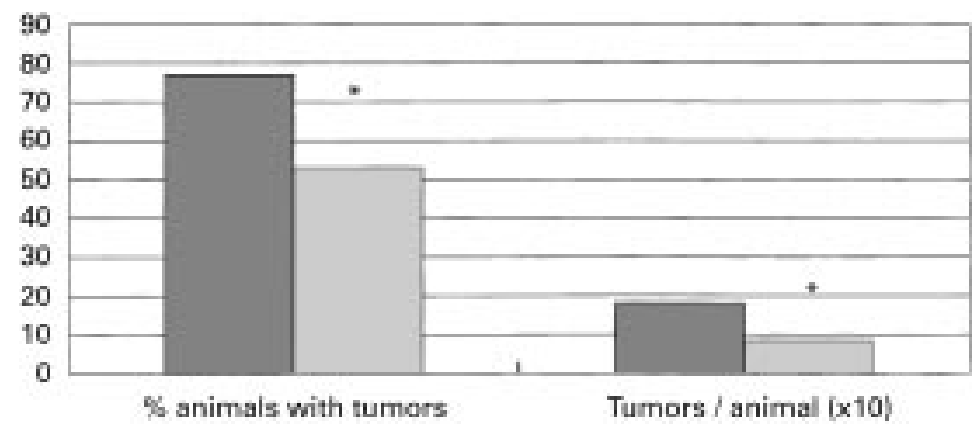

Fig. 4. Bifidobacteria prevent colon tumorigenesis, pre- and post-initiation application. Data from Reddy, (1998). $\square=$ Control 3, $=2 \%$ Bifidobacteria.

are glucuronide metabolites of the carcinogenic food contaminants, heterocyclic amines. They need to be cleaved by $\beta$-glucuronidases before being activated to the ultimate carcinogens, delivering the electrophilic species (Turesky et al. 1991). Other examples are azoreductases that activate azo dyes, some of which were formally used as food colouring agents. Nitroaromatics are activated by nitroreductases and are environmental contaminants that may reach the gut via blood or bile; whereas 7 - $\alpha$-dehydroxylase may contribute to the genotoxic burden in the gut lumen by activating endogenous hormones to intermediates that are further converted to yield reactive oxygen species (ROS). Harmful and beneficial bacteria commonly found in the intestine differ in their enzyme activities (Ballongue et al. 1997). Bifidobacteria and Lactobacilli have lower activities of these xenobiotic-metabolising enzymes than
Bacteroides, Clostridia and Enterobacteriaceae. For example, $\beta$-glucuronidase is highest in Enterobacteria and Clostridia (Morra \& Boland, 1995). As a consequence of these enzymes, toxic compounds, already detoxified in the liver by conjugation, are regenerated by the release of toxic aglycones. Furthermore, products formed after hydrolysis of glucuronides can re-enter enterohepatic circulation and thus delay excretion of compounds. Therefore, although no specific evidence is available, (other than these general associative suggestions), lower activities of these enzymes are connected to lower carcinogen exposures. In contrast, an increase of $\beta$-glucosidase could potentially be regarded as an advantage for health by releasing glycosides of plant ingredients, some of which have more antimutagenic, antioxidative, anticarcinogenic and immune stimulatory properties than their respective glycosides.

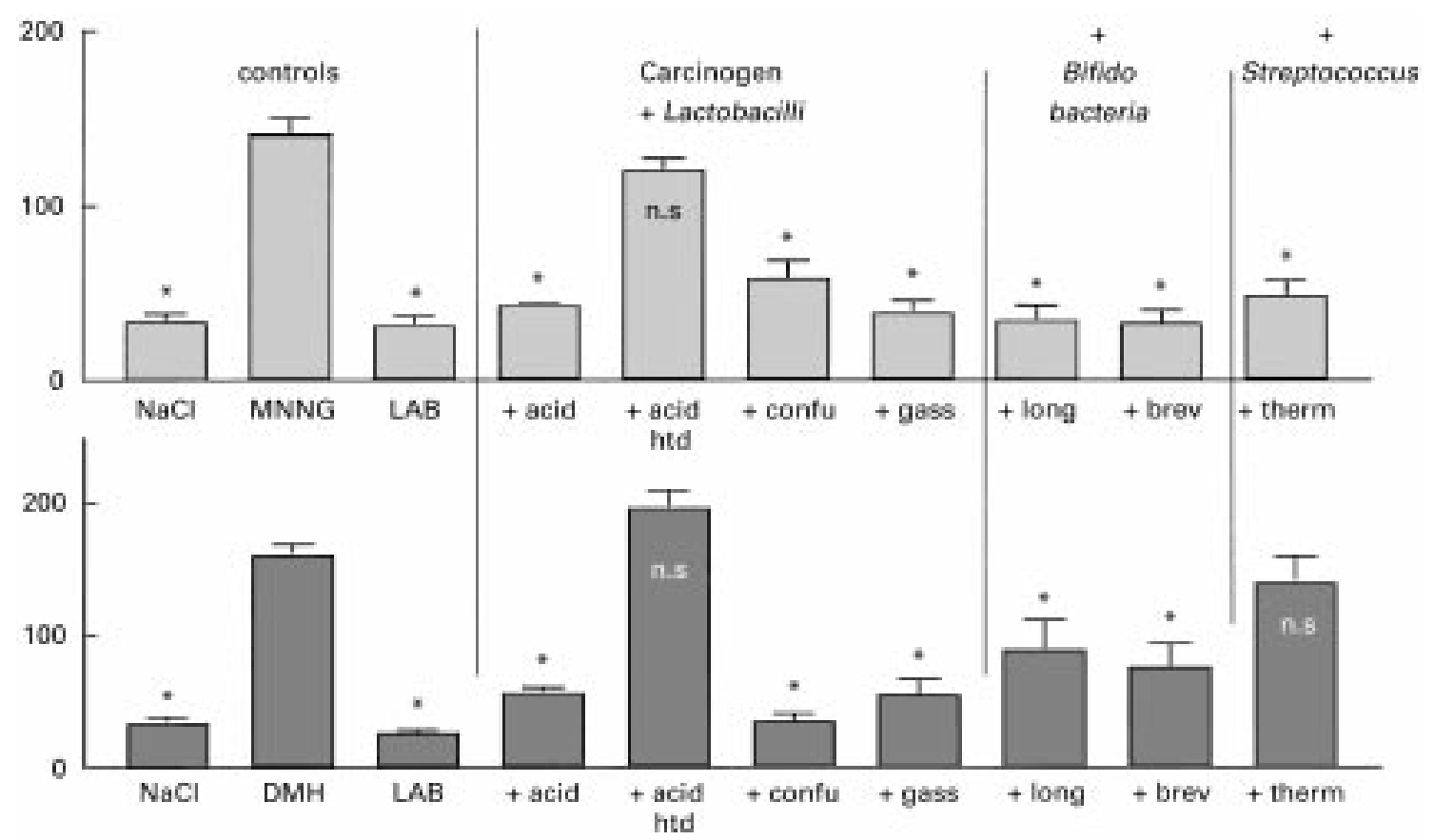

Fig. 5. Bifidobacteria prevent $N$-methyl- $N$-nitroso- $N$-nitroguanidine (MNNG)- or 9,2-dimethylhydrazine (DMH) - induced DNA-damage in the colon of rats in vivo. Abbreviations are: LAB, lactic acid producing bacteria; + , designates the combinational treatment groups with both carcinogen and LAB; acid, L. acidophilus; htd, heat inactivated; confu, L. confusus; gass, L. gasseri; long, B. brevi; therm; S. thermophilus. Data from Pool-Zobel et al. (1996) and Wollowski et al. (1999). 

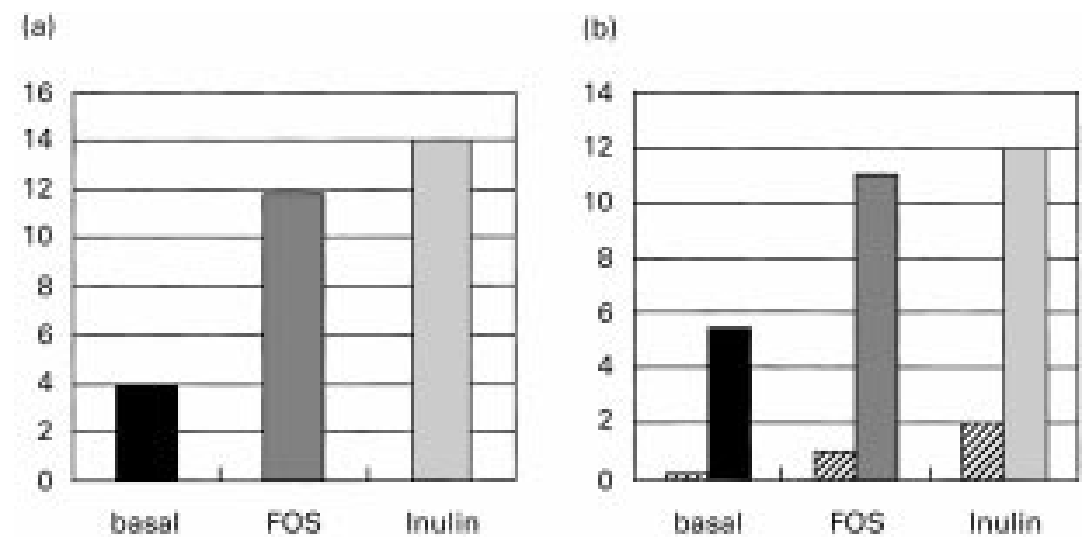

Fig. 6. Inulin and oligofructose added to the diet increase DMH-induced apoptosis, as detected by the tunnel assay. Data from Hughes \& Rowland (2001). a) $\mathbf{\square}=$ basal, $\mathbf{\square}=$ FOS, $\square=$ Inulin. b) $\mathbb{2}=$ proximal, $\square=$ distal.

The impact of inulin on enzyme activities follows a pattern that could be regarded as potentially beneficial in two studies whereas in other studies the enzyme levels remain unaltered (Kleessen et al. 1997; Roland et al. 1994). Since Bifidobacteria can have regulatory effects on the growth of other colonic bacteria, inulin could cause this regulation indirectly by leading to a selective stimulation of Bifidobacteria (Gibson \& Wang, 1994).

Diet could also be important for enzyme-related detoxifying effects in the colon. Only recently, we have obtained evidence showing that resistant starch can induce the chemopreventive enzyme glutathione S-transferase $\pi(\mathrm{GST} \pi)$ in the colon of rats with human flora (Treptow-van Lishaut et al. 1999). In contrast, studies by other groups showed that inulin fed to rats inoculated with whole faecal flora enhanced hepatic GST-activity, but did not modulate GST in the colon (Roland et al. 1996). This interaction of gut flora with cells of the colonic mucosa or other systemically remote tissues and expression of GST and other xenobiotic metabolising enzymes has only been randomly investigated so far. In the future related studies on these aspects may reveal how inulin can be protective. Together the findings imply that there is some potential of pro- and prebiotics to inactivate carcinogenic factors in the colon. However, more conclusive evidence is needed to relate these activities to a lowering of cancer risk either by modulating luminal or even colon epithelial metabolism.

\section{Effects of inulin and gut-products on apoptosis}

Apoptosis, first described by Kerr et al. (1972), is a physiological process of selected cell deletion. As an antagonist of cell proliferation, apoptosis contributes to keeping the cell number in tissues and organs constant, and helps to remove superfluous and damaged cells. If apoptosis is suppressed (e.g. in cells with p53-mutations) this can result in the development of various tumours (Hollstein et al. 1991). Similarly, for example overexpression of the antiapoptotic gene $b c l-2$ can lead to lymphoid hyperplasia, lymphomas, and auto-aggression by self-reactive lymphocytes that are normally deleted by apoptosis. In contrast, the induction of apoptosis is essential for the therapy of neoplasm and autoimmune diseases (Thompson, 1995; Kroemer et al. 1995). During apoptosis the cells undergo various morphological and molecular changes, e.g. the formation of apoptotic blebs of the cell membrane, DNA-fragmentation in typical fragments of 180 base pairs (characteristic DNAladdering), condensation of chromatin, or the externalization of phosphatidylserine (PS) on the extracellular side of the plasma membrane (Cohen, 1993; Kroemer et al. 1995; Hale et al. 1996; Steller, 1995). These changes can be detected in a great number of apoptosis assays.

To study the impact of inulin on apoptosis as a mechanism for anticancer properties of prebiotics, young (3-4 weeks old) male Sprague-Dawley rats $(n=6)$ were fed a diet containing either inulin $(5 \%)$ or oligofructose $(5 \%)$ or the basal diet only for a period of 3 weeks. At the end of this period they all were gavaged with a dose of $20 \mathrm{mg} / \mathrm{kg}$ of 9.12-dimethylhydrazine (DMH) directly in the stomach. Twenty-four hours later the animals were killed. The colon was removed and cut mid-way, to obtain a proximal and distal end, and subsequently adequately embedded in paraffin wax. The apoptotic bodies in twenty good longitudinal sections of crypts were counted microscopically upon identification by means of the Apoptag kit (Appligene-Oncor, France) (Hughes \& Rowland, 2001). The results clearly show that there was an effect on apoptosis. Feeding either inulin or oligofructose to the rats increased their apoptotic index (Fig. 6), which means that the prebiotic fed rats more efficiently eliminate colonic cells with defective DNA. Here the effect of inulin was numerically more important than the effect of oligofructose. It is remarkable that this is the case both in the proximal and in the distal colon (Hughes \& Rowland, 2001).

\section{Short-chain fatty acids, products of gut fermentation}

One of the bacterial metabolites of fructan fermentation is butyrate, a short-chain fatty acid, which is one of the most physiologically relevant products of gut flora fermentation (Cummings et al. 1987). It is found in millimolar concentrations in the lumen as a consequence of microbial 
carbohydrate degradation and serves as a principle energy source for colon epithelial cells (Roediger, 1989). A hypothesis is that butyrate protects against colon cancer by inhibiting colon cell proliferation and inducing differentiation (Rehman et al. 1998; Sesink et al. 2000). Moreover, it may additionally confer protection by promoting apoptosis in colon tumour cell lines (Hague et al. 1995; Hague \& Paraskeva, 1995). It is further implicated that dietary fibre may protect against colon cancer through the production of butyrate by the colonic microflora (Van Munster et al. 1994; McIntyre et al. 1993; Perrin et al. 2001). Therefore some of the properties inulin has shown in rats in vivo, including the first described mechanisms of apoptosis, could be due to butyrate.

In contrast, in vitro data with human biopsy specimens and other in vivo data in animals, show that butyrate seems to have opposite effects in non-transformed colon cells where it acts proliferate instead of antiproliferative (Lupton, 1995). For diet and cancer prevention therefore, some additional mechanisms could be caused by butyrate in non-transformed colon cells. In fact, the blocking agent activities involved in primary cancer prevention are expected to be of equal importance for overall risk reduction (Wattenberg, 1992). These activities lead to reduced exposure to genotoxic risk factors either by inhibiting their formation, by scavenging reactive intermediates or by modulating the balance of metabolizing systems in cells to favour deactivation of carcinogens (Johnson et al. 1994). In this context we have recently been able to show that pre-incubation of human and rat primary colon cells with Na-butyrate protects them from genotoxic effects induced by hydrogen peroxide (Abrahamse et al. 1999; Pool-Zobel et al. 1995). Butyrate may also alter the metabolic balance in human colon tumour cell lines by inducing glutathione S-transferase (GST) (Stein et al. 1996; Kirlin et al. 1999). GST are a family of enzymes that catalyze the conjugation of reactive chemicals with glutathione (GSH) and play a major role in protecting cells from these chemicals (Awasthi et al. 1994). GSH-conjugates are subsequently eliminated via active transport systems (Ishikawa, 1992). In human and rat colon tissue, GSTP1 is the major form of this enzyme and it is inducible by dietary factors (Peters et al. 1989; Acheson et al. 1967; van Lieshout et al. 1996; Nijhoff et al. 1995). Butyrate may also increase secretion of mucin, a barrier which can deactivate carcinogens thus protecting the epithelial cells (Kassie et al. 1999). Together the findings are subsequently the possible extensions in the line of evidence that fibre may be protective on account of butyrate production by the gut flora. In this context, an interesting recent study has shown that only fibres promoting a stable butyrate colonic ecosystem decrease the rate of aberrant crypt foci in rats (Perrin et al. 2001).

\section{Conclusion}

From the present set of results, it can be stated that there is consistent data available suggesting that the prebiotic chicory inulin and its fractions have anticarcinogenic activities, most probably through particular modification and maintenance of metabolic activity of the intestinal flora.

In rats a prebiotic effect, resulting in the proliferation of bifidobacteria (with the major metabolites lactate or acetate), as well as of other bacteria (with the metabolites butyrate or propionate and acetate), could be responsible for the observed anticancer effects in the colon of animals. The metabolites will reduce the $\mathrm{pH}$ of the colon lumen and direct interactions with cells of the colon epithelium may cause enhanced expression of phase II (deactivating enzymes), such as GST, or induce apoptosis to remove transformed cells, or increase mucin, a barrier which protects from attack by reactive compounds.

Since there is established evidence of a prebiotic effect in humans, these data justify further research with human volunteers using biomarkers to reveal a potential risk reduction in the gut lumen. Appropriate methods to determine the genotoxic burden in the gut lumen, or to analyse DNA damage and other parameters in cells isolated from colon biopsy specimens, are available. On the basis of so far obtained preliminary results they are probably sufficiently sensitive to reveal a significant effect of inulin or oligofructose intervention, if present (Osswald et al. 2000; Pool-Zobel \& Leucht, 1997; Pool-Zobel et al. 1999). Such studies would allow evaluating the possible role of these food ingredients to reduce carcinogenic/genotoxic risk factors in the colon.

At present a human intervention study is being planned, and its outcome promises to yield more information in the potentially advantageous properties of inulin and related prebiotics in the human colon.

\section{Acknowledgements}

The results described in this paper are part of the basis of a human dietary intervention study (SYNCAN,QLK1-1999346) sponsored by the EU.

\section{References}

Abrahamse SL, Pool-Zobel BL \& Rechkemmer G (1999) Potential of short chain fatty acids to modulate the induction of DNA damage and changes in the intracellular calcium concentration in isolated rat colon cells. Carcinogenesis 20, 629-634.

Acheson ED, Hadfield EH \& Macbeth RG (1967) Carcinoma of the nasal cavity and accessory sinuses in woodworkers. The Lancet 2/11, 311-312.

Awasthi YC, Sharma R \& Singhal SS (1994) Human glutathione S-transferases. International Journal of Biochemistry 26, 295-308.

Ballongue J, Schumann C \& Quignon P (1997) Effects of lactulose and lactitol on colonic microflora and enzymatic activity. Scandinavian Journal of Gastroenterology 32, Suppl. 222, 41-44.

Bird RP (1987) Observation and quantification of aberrant crypts in the murine colon treated with a colon carcinogen: preliminary findings. Cancer Letters 37, 147-151.

Bolognani F, Rumney CJ, Coutts JT, Pool-Zobel BL \& Rowland IR (2001) Effect of lactobacilli, bifidobacteria and inulin on the formation of aberrant crypt foci in rats. European Journal of Nutrition 40, 293-300.

Cohen JJ (1993) Apoptosis. Immunology Today 14, 126-130.

Coles B, Yang M, Lang NP \& Kadlubar FF (2000) Expression of 
hGSTP1 alleles in human lung and catalytic activity of the native protein variants towards 1-chloro-2,4-dinitrobenzene, 4-vinylpridine and (+)-anitbenzo[a]pyrene-7,8-diol-9,10-0x9de. Cancer Letters 156, 167-175.

Coudray C, Bellanger J, Castiglia-Delavaud C, Remesy C, Vermorel M \& Rayssiguier Y (1997) Effect of soluble or partly soluble dietary fibres supplementation on absorption and balance of calcium, magnesium, iron and zinc in healthy young men. European Journal of Clinical Nutrition 51, 375-380.

Cummings JH, Pomare EW, Branch WJ, Naylor CPE \& Macfarlane GT (1987) Short chain fatty acids in human large intestine, portal, hepatic and venous blood. Gut 28, 1221-1227.

Den Hond EM, Geypens B \& Ghoos Y (2000) Effect of high performance chicory inulin on constipation. Nutrition Research 20, 731-736.

Doll R (1991) The lessons of life: Keynote address to the Nutrition and Cancer Conference. Cancer Research 52, Supplement, 2024S-2029S.

Doll R (1996) Nature and nurture: possibilities for cancer control. Carcinogenesis 17, 177-184.

Doll R \& Peto R (1981) The causes of cancer: Quantitative estimates of avoidable risks of cancer in the United States today. Journal of the National Cancer Institute 66, 1191-1308.

Ellgard L, Andersson H, Bosaeus I \& Bosaeus I (1997) Inulin and oligofructose do not influence the absorption of cholestrol, or the excretion of cholesterol, $\mathrm{Ca}, \mathrm{Mg}, \mathrm{Zn}, \mathrm{Fe}$, or bile acids but increase energy excretion in ileostomy subjects. European Journal of Clinical Nutrition 45, 451-457.

Fearon ER (1997) Human cancer syndromes: Clues to the origin and nature of cancer. Science 278, 1043-1050.

Gallaher DD \& Khil J (1999) The effect of synbiotics on colon carcinogenesis in rats. Journal of Nutrition 129, 1483S-1487S.

Gibson GR, Beatty ER, Wang X \& Cummings J (1995) Selective stimulation of bifidobacteria in the human colon by oligofructose and inulin. Gastroenterology 108, 975-982.

Gibson GR \& Roberfroid MB (1995) Dietary modulation of the human colonic microbiota: Introducing the concept of prebiotics. Journal of Nutrition 125, 1401-1412.

Gibson GR \& Wang X (1994) Regulatory effects of bifidobacteria on the growth of other colonic bacteria. Journal of Applied Bacteriology 77, 412-420.

Hague A, Elder DJE, Hicks DJ \& Pareskeva C (1995) Apoptosis in colorectal tumour cells: Induction by the short chain fatty acids butyrate, propionate and acetate and by the bile salt deoxycholate. International Journal of Cancer 60, 400-406.

Hague A \& Paraskeva C (1995) The short-chain fatty acid butyrate induces apoptosis in colorectal tumour cell lines. European Journal of Cancer Prevention 4, 359-364.

Hale AJ, Smith CA, Sutherland LC, Stoneman VEA, Longthorne VL, Culhane AC \& Williams GT (1996) Apoptosis: molecular regulation of cell death. European Journal of Biochemistry 236, 1-26.

Hollstein M, Sidransky D, Vogelstein B \& Harris CC (1991) P53 mutations in human cancers. Science 253, 49-53.

Hughes R \& Rowland IR (2001) Stimulation of apoptosis by two prebiotic chicory fructans in the rat colon. Carcinogenesis 22 , 43-47.

Ishikawa T (1992) The ATP-dependent glutathione S-conjugate export pump. TIBS 17, 463-468.

Johnson IT, Williamson G \& Musk SRR (1994) Anticarcinogenic factors in plant foods: A new class of nutrients? Nutrition Research Reviews 7, 175-204.

Kassie F, Pool-Zobel BL, Parzefall W, Schulte-Hermann R \& Knasmuller S (1999) Investigations on the genotoxic effects of benzylisothiocyanate, a natural chemopreventive agent. Mutagenesis 14, 595-603.

Kerr JFR, Wyllie AH \& Currie AR (1972) Apoptosis: a basic biological phenomenon with wide ranging implications in tissue kinetics. British Journal of Cancer 26, 239-257.

Kirlin WG, Cai J, Delong MJ, Patten EJ \& Jones DP (1999) Dietary compounds that induce cancer preventive phase 2 enzymes activate apoptosis at comparable doses in HT29 colon carcinoma cells. Journal of Nutrition 129, 1827-1835.

Kleessen B, Sykura B, Zunft HJ \& Blaut M (1997) Effects of inulin and lactose on fecal microflora, microbial activity, and bowel habit in elderly constipated persons. American Journal of Clinical Nutrition 65, 1397-1402.

Kroemer G, Petit P, Zamzami N, Vayssiere JL \& Mignotte B (1995) The biochemistry of programmed cell death. FASEB Journal 9, 1277-1287.

Kruse HP, Kleessen B \& Blaut M (1999) Effects of inulin on faecal bifidobacteria in human subjects. British Journal of Nutrition 82, 375-382.

Ling WH, Korpela R, Mykkanen H, Salminen S \& Hanninen O (1994) Lactobacillus strain Gg supplementation decreases colonic hydrolytic and reductive enzyme activities in healthy female adults. Journal of Nutrition 124, 18-23.

Lupton JR (1995) Butyrate and colonic cytokinetics: differences between in vitro and in vivo studies. European Journal of Cancer Prevention 4, 373-378.

Magnuson B, Carr I \& Bird RP (1993) Ability of aberrant crypt foci characteristics to predict colonic tumor incidence in rats fed cholic acid. Cancer Research 53, 4499-4504.

McIntyre A, Gibson PR \& Young GP (1993) Butyrate production from dietary fibre and protection against large bowel cancer in a rat model. Gut 34, 386-391.

Morra G \& Boland CR (1995) Heriditary nonpolyposis colorectal cancer: the syndrome, the genes and historical perspectives. Journal of the National Cancer Institute 87, 1114-1125.

Moshfegh AJ, Friday JE, Goldman JP \& Chug-Ahuja JK (1999) Presence of inulin and oligofructose in the diets of Americans. British Journal of Nutrition 129, 1407S-1411S.

Mutanen M, Pajari AM \& Oikarinen SI (2000) Beef induces and rye bran prevents the formation of intestinal polyps in Apc $c^{\text {Min }}$ mice: relation to $\beta$-catenin and $\mathrm{PKC}$ isozymes. Carcinogenesis 21, 1167-1173.

Nijhoff WA, Mulder TPJ, Verhagen H, Van Poppel G \& Peters WHM (1995) Effects of consumption of Brussels sprouts on plasma and urinary glutathione S-transferase class- $\alpha$ and $-\pi$ in humans. Carcinogenesis 16, 955-957.

Osswald K, Becker TW, Grimm M, Jahreis G \& Pool-Zobel BL (2000) Inter- and Intra-individual variation of faecal water genotoxicity in human colon cells. Mutation Reserch $\mathbf{4 7 2}$, 59-70.

Pereira MA, Barnes LH, Rassman VL, Kelloff GV \& Steele VE (1994) Use of azoxymethane-induced foci of aberrant crypts in rat colon to identify potential cancer chemopreventive agents. Carcinogenesis 15, 1049-1054.

Perrin P, Pierre F, Patry Y, Champ M, Berreur M, Pradal G, Bornet P, Meflah K \& Menenteau J (2001) Only fibres promoting a stable butyrate producing colonic ecosystem decrease the rate of aberrant crypt foci in rats. Gut 48, 53-61.

Peters WHM, Roelofs HMJ, Nagengast FM \& Van Tongeren JHM (1989) Human intestinal glutathione S-transferases. Biochem Journal 257, 471-476.

Pierre F, Perrin P, Champ M, Bornet F, Meflah K \& Menanteau J (1997) Short chain fructo- oligosaccharides reduce the occurrence of colon tumors and develop gut associated lymphoid tissue in Min mice. Cancer Research 57, 225-228.

Pool-Zobel BL, Abrahamse SL, Collins AR, Kark W, Gugler R, Oberreuther D, Siegel EG, Tretow-Van Lishaut S \& Rechkemmer G (1999) Analysis of DNA strand breaks, oxidized bases and glutathione S-transferase P1 in human colon cells. Cancer Epidemiology Biomedical Preview 8, 609-614. 
Pool-Zobel BL, Abrahamse SL \& Rechkemmer G (1995) Pretreatment of colon cells with sodium butyrate but not isobutyrate protects them from DNA damage induced by hydrogen peroxide. Proceedings, (Abstract).

Pool-Zobel BL \& Leucht U (1997) Induction of DNA damage in human colon cells derived from biopsies by suggested risk factors of colon cancer. Mutation Research 375, 105-116.

Pool-Zobel BL, Neudecker C, Domizlaff I, Ji S, Schillinger U, Rumney CJ, Moretti M, Villarini M, Scassellati-Sforzolini G \& Rowland IR (1996) Lactobacillus- and Bifidobacteriummediated antigenotoxicity in colon cells of rats: Prevention of carcinogen-induced damage in vivo and elucidation of involved mechanisms. Nutrition Cancer 26, 365-380.

Reddy BS (1998) Prevention of colon cancer by pre and probiotics: evidence from laboratory studies. British Journal of Nutrition 80, S219-S223.

Reddy BS, Hamid R \& Rao CV (1997) Effect of dietary oligofructose and inulin on colonic preneoplastic aberrant crypt foci inhibition. Carcinogenesis 18, 1371-1374.

Rehman A, Collis CS, Yang M, Kelly M, Diplock AT, Halliwell B \& Rice-Evans CA (1998) The effects of iron and vitamin C co-supplementation on oxidative dmage to DNA in healthy volunteers. Biochemistry Biophysiology Research Commun 246, 293-298.

Roberfroid MB, Van Loo J \& Gibson GR (1998) The Bifidogenic nature of chicory inulin and its hydrolysis products. Journal of Nutrition 128, 11-19.

Roediger WEW (1989) The utilisation of nutrients by isolated epithelial cells of the rat colon. Gastroenterology 83, 424-429.

Roland N, Migpm-Baudon L, Flinois JP \& Beaune PH (1994) Hepatic and Intestinal cytochrome P450, Glutathone s-transferase and UDP Glucuronosyl transferase are affected by six types of dietary fiber in rats inoculated with human whole fecal flora. Journal of Nutrition 124, 1581-1587.

Roland N, Rabot B \& Nugon-Baudon L (1996) Modulation of the biological effects of glucosinolates by inulin and oat fibre in gnotobiotic rats inoculated with a human whole faecal flora. Food and Chemical Toxicology 34, 671-677.

Rowland IR (1991) Nutrition and gut flora metabolism. In Nutrition, Toxicity and Cancer, pp. 113-136 [IR Rowland, editor]. Boca Raton, FL: CRC Press.

Rowland IR, Rumney CJ, Coutts JT \& Lievense LC (1998) Effect of Bifidobacterium longum and inulin on gut bacterial metabolism and carcinogen-induced aberrant crypt foci in rats. Carcinogenesis 19, 281-285.

Saavedra JM, Tscherina A, Moore N, Abi-Hanna A, Coletta F, Emenhiser C \& Yolken RH (1999) Gastro-ntestinal function in infants consumin a weaning food supplemented with oligofructose, a prebiotic. Journal of Paediatrics, Gastroenterology and Nutrition 29, A95.

Schneemann BO (1999) Fiber, inulin and oligofructose: similarities and differences. British Journal of Nutrition 129, $1424 \mathrm{~S}-1427 \mathrm{~S}$.

Sesink ALA, Termont DSML, Kleibeuker JH \& Van der Meer R (2000) Red meat and colon cancer: dietary heme, but not fat, has cytotoxic and hyperproliferative effects on rat colonic epithelium. Carcinogenesis 21, 1909-1915.

Singh J, Rivenson A, Tomita M, Shimamura S, Ishibashi N \& Reddy BS (1997) Bifidobacterium longum, a lactic acid-producing intestinal microflora inhibit colon cancer and modulate the intermediate biomarkers of colon carcinogenesis. Carcinogenesis 18, 1371-1377.

Stein J, Schroder O, Bonk M, Oremek G, Lorenz M \& Caspary WF (1996) Induction of glutathione-S-transferase-pi by short- chain fatty acids in the intestinal cell line Caco-2. European Journal of Clinical Investigation 26, 84-87.

Steller H (1995) Mechanisms and genes of cellular suicide. Science 267, 1445-1449.

Thompson CB (1995) Apoptosis in the pathogenesis and treatment of disease. Science 267, 1456-1462.

Treptow-van Lishaut S, Rechkemmer G, Rowland IR, Dolara P \& Pool-Zobel BL (1999) The carbohydrate crystalean and colonic microflora modulate expression of glutathione S-transferase subunits in colon of rats. European Journal of Nutrition 38, $76-83$.

Turesky RJ, Lang NP, Butler MA, Teitel CH \& Kadlubar FF (1991) Metabolic activation of carcinogenic heterocyclic aromatic amines by human liver and colon. Carcinogenesis $\mathbf{1 2}$, $1839-1845$.

Van den Heufel E, Muys T, Van Dokkum W \& Schaafsma G (1999) Oligofructose stimulates calcium absorption in adolescents. American Journal of Clinical Nutrition 35, 525-552.

Van Lieshout EMM, Peters WHM \& Jansen JB (1996) Effect of oltipraz, alpha-tocopherol, betacarotene and phenethylisothiocyanate on rat oesopageal, gastric, colonic and heptatic glutathone, glutathione S-transferase and peroxidase. Carcinogenesis 17, 1439-1445.

Van Loo J, Coussement P, De Leenheer L, Hoebregs H \& Smits G (1995) On the presence of inulin and oligofructose as natural ingredients in the Western diet. Crititcal Reviews of Food Science Nutrition 35, 525-552.

Van Loo J, Cummings JH, Delzenne N, Englyst HN, Franck A, Hopkins MJ, Kok N, Macfarlane GT, Newton DF, Quigley ME, Roberfroid MR, van Vliet T \& Van den Heuvel EGH (1999) Functional food properties of non digestible oligosaccharides: a consensus report from the ENDO project (DGXII AIRII-CT94-1095). British Journal of Nutrition 81, $121-132$.

Van Loo J \& Jonkers N (2001) Evaluation in human volunteers of the potential anticarcinogenic activities of novel nutritional concepts prebiotics, probiotics and synbiotics (the SYNCAN project QLK1-1999-00346). Nutrition Metabolism Cardiovascular Disease 11, Suppl to No 4, 87-93.

Van Munster IP, Tangerman A \& Nagengast FM (1994) Effect of resistant starch on colonic fermentation, bile acid metabolism, and mucosal proliferation. Digestive Diseases and Sciences 39, 834-842.

Verghese M, Rao DR, Chawan CB \& Schackelford LA (2002a) Dietary inulin suppresses azoxymethane-induced preneoplastic aberrant crypt foci in mature Fisher-344 rats. Journal of Nutrition (in press).

Verghese M, Rao DR, Williams LL \& Schackelford LA (2002b) Dietary inulin suppresses azoxymethane-induced aberrant crypt foci and colon tumors at the promotion stage in Fisher-344 rats. Journal of Nutrition (in press).

Wargovich MJ, Harris C, Chen CD, Palmer C, Steele VE \& Kelloff G (1992) Growth kinetics and chemoprevention of aberrant crypts in the rat colon. Journal of Cellular Biochemistry 15G, Supplement, 51-54.

Wattenberg LW (1992) Inhibition of carcinogenesis by minor dietary constituents. Cancer Research 52, Suppl., 2085S2091S.

Williams CM (1999) Effects of inulin on lipid parameters in humans. British Journal of Nutrition 129, 1471S-1473S.

Wollowski I, Ji S, Bakalinsky AT, Neudecker C \& Pool-Zobel BL (1999) Bacteria used for the production of yogurt inactivate carcinogens and prevent DNA damage in the colon of rats. Journal of Nutrition 129, 77-82. 